\title{
You Talk, We Understand-The Importance of a Common Language of Measurement ${ }^{+}$
}

\author{
Vicki J Barwick \\ UK National Measurement Laboratory for Chemical and Bio-Measurement, LGC, Queens Road, Teddington, \\ Middlesex TW11 0LY, UK; vicki.barwickl@lgcgroup.com \\ + Presented at the Virtual Eurachem Workshop 2020 - “Quality Assurance for Analytical Laboratories in the \\ University Curriculum", 14-15 July 2020; Available online: https://eurachem2020.ro/.
}

Published: 23 October 2020

Keywords: metrology; terminology

The basic principles of metrology (the science of measurement) are the same across disciplines. Increasingly, scientists work in interdisciplinary teams. It is therefore important to have a common 'language of measurement', to aid communication. The International Vocabulary of Metrology (VIM) was produced to provide this common language. The third edition of 'the VIM' was produced by WG2 of the Joint Committee for Guides in Metrology (JCGM) and published as JCGM 200:2008 and as ISO/IEC Guide 99 [1]. A revised version of JCGM 200 was published in 2012 [2]. Having a clear set of definitions should reduce disputes and misunderstandings, and allow for a consistent interpretation of concepts, for example between regulatory or assessment bodies and laboratories. The availability of clear definitions also aids translation of standards and guidance documents.

In 2012, Eurachem published the guide 'Terminology in Analytical Measurement-Introduction to VIM 3' [3]. The guide aims to put the definitions that are most important to analytical scientists in a context that they will hopefully recognize. It is applicable across a range of sectors, including chemical and bio-measurement. The guide identifies the most important concepts and terms requiring particular attention. It also highlights where the terminology commonly used in laboratories differs from the VIM terms. The target audience for the guide includes laboratory staff, accreditation bodies, those commissioning measurements, those using measurement results and lecturers and trainers involved with teaching aspects of metrology.

This presentation will provide an overview of the structure of the VIM and the Eurachem guide, and discuss some of the concepts which often cause confusion in laboratories.

\section{References}

1. ISO/IEC Guide 99:2007. International Vocabulary of Metrology-Basic and General Concepts and Associated Terms (VIM); ISO/IEC: Geneva, Switzerland, 2007.

2. JCGM 200:2012. International Vocabulary of Metrology-Basic and General Concepts and Associated Terms (VIM). Available online: www.bipm.org (accessed on 21 October 2020).

3. Barwick, V.J.; Prichard, E. (Eds.) Eurachem Guide: Terminology in Analytical Measurement-Introduction to VIM 3, 1st ed.; Eurachem: 2011; ISBN 978-0-948926-29-7. Available online: www.eurachem.org (accessed on 21 October 2020).

Publisher's Note: MDPI stays neutral with regard to jurisdictional claims in published maps and institutional affiliations.

(C) 2020 by the authors. Licensee MDPI, Basel, Switzerland. This article is an open access article distributed under the terms and conditions of the Creative Commons Attribution (CC BY) license (http://creativecommons.org/licenses/by/4.0/). 